\title{
ANGEL OF THE LORD: MESSENGER OR EUPHEMISM?
}

\author{
Stephen L. White
}

\begin{abstract}
Summary
The figure of the 'angel of the LORD' as a messenger is a familiar one throughout the Bible. But in a number of passages the angel speaks, acts, and is addressed not as a messenger, but as God himself. In some passages the text switches from angel of the LORD to God, and in others there is a juxtaposition of God and the angel of the LORD. This paper suggests that the phrase 'angel of the LORD' is a euphemism for God used both to create tension in the narrative and to emphasise the transcendence of Yahweh.
\end{abstract}

\section{Introduction}

The figure of the 'angel of the LORD' as a messenger is a familiar figure throughout the Bible and particularly in the Old Testament. Indeed, the word angel comes from the Greek $\alpha \gamma \gamma \varepsilon \lambda$ o $\varsigma$ and means 'messenger' or 'one who is sent'. A close reading of the Old Testament that carefully considers context will reveal that in a number of passages the angel speaks, acts, and is addressed not as a messenger, but as God himself. In some passages the text switches from angel of the LORD to God, and in others there is a more subtle but nonetheless clear juxtaposition of God and the angel of the LORD. Indeed, after noting that the 'angel of the LORD' is a common device in OT narrative, Noll goes on to say, 'The most remarkable and persistent feature of this tradition is the interchangeability of Yahweh and his angel.' ' This paper will examine this phenomenon to explore why this interchangeable use of the phrase 'angel of the LORD' and LORD or God occurs.

Heidt says it makes no theological difference how God chooses to communicate with humanity. ${ }^{2}$ This is certainly true, but it is also true

1 S.F. Noll, Angelology in the Qumran Texts (Thesis for Doctor of Philosophy, The Victoria University of Manchester, 1979), 18.

2 W.G. Heidt, Angelology of the Old Testament: A Study in Biblical Theology 
that how this communication is portrayed does have theological significance as Heidt himself later acknowledges.

\section{The angel of the LORD in Hebrew and Greek}

The Hebrew word used in the passages we will examine is măl'ak

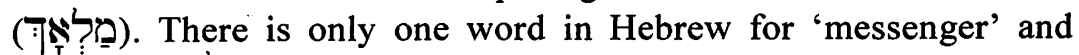

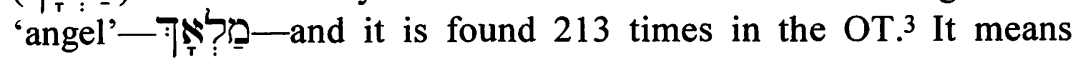
messenger or representative, both human and divine. It can also be the word for a theophanic angel; that is, a manifestation of God. It is this latter meaning that we shall explore in this paper-the sense of the angel as a kind of 'stand-in' for Yahweh. More particularly, we are

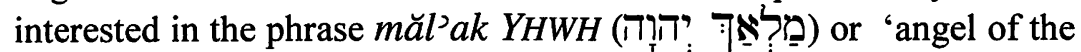
LORD'. This phrase appears forty-eight times in forty-five verses in

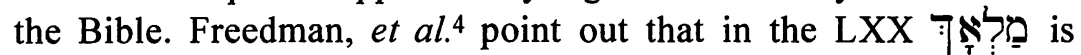
translated as ö $\gamma \gamma \varepsilon \lambda \circ \varsigma$ in keeping with the usage of Classical Greek. However, the Vulgate differentiates nuntius (a messenger of human beings) from angelus (a messenger of God).

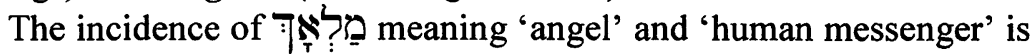
divided in the OT. The divine messenger is usually signified by a

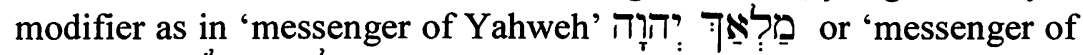

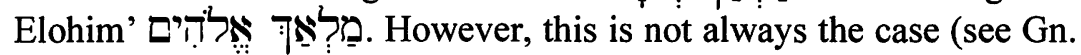
48:16; $1 \mathrm{Ki}$. 13:18; 19:5; Ps. 78:49; 91:11; Job 33:23). The word פֵַ alone with the meaning 'angel' appears as early as Hosea 12:5. A number of cases are fairly ambiguous such as Judges $2: 1,4$; Isaiah 44:26; Malachi 3:1; Job 4:18; and Ecclesiastes 5:5. This ambiguity seems to carry over into the LXX where ö $\gamma \gamma \varepsilon \lambda \circ \varsigma$ is used for angels or men but $\pi \rho \varepsilon \dot{\sigma} \beta \nu \varsigma$ is often used for human messengers. 5

\section{The appearances}

Newsom observes that the early writings in which the angel of the LORD appears do not display any interest in the heavenly messengers themselves. 'They are not individuated in any way.' 6 When humans

(Washington, DC: The Catholic University of America Press, 24:1949), 70.

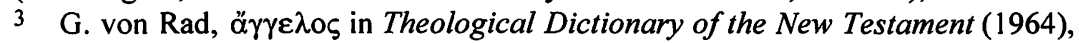
74-80.

4 D.N. Freedman, B.E. Willoughby et al., מִלְ in Theological Dictionary of the Old Testament (Grand Rapids, MI: William B. Eerdmans Publishing Co., 1997), 308-25.

5 D.N. Freedman, B.E. Willoughby et al.,

6 C.A. Newsom, 'Angels' in The Anchor Bible Dictionary (New York: 
see the angel their reactions vary. In some passages there is no reaction at all (Gn. 19) and in some there is reverence (Jos. 5:14-15).

The first appearance of this interchangeability of the angel of the LORD and Yahweh appears in Genesis 16 where we have the angel of the LORD appearing to Hagar.

The next appearance in which the messengers of the LORD and the LORD himself are used interchangeably does not actually mention an angel, but it is too important to ignore and shares some features with the other passages we shall discuss. It is in Genesis 18:1-16 where the three young men visit Abraham and Sarah. This was interpreted by early Christian writers as scriptural evidence for the Trinity since the interchangeability of the LORD (singular) and the three young men (plural) occurs from the outset and throughout the pericope. But this interpretation has been rejected in light of recent exegetical scholarship.7 Below is a tabular representation of the singular and plural references to the visitor(s) to Abraham and Sarah:

\begin{tabular}{|c|c|}
\hline $\begin{array}{c}\text { Singular pronouns or references } \\
\text { to 'the LORD' }\end{array}$ & $\begin{array}{c}\text { Plural pronouns or references to } \\
\text { the three young men }\end{array}$ \\
\hline $18: 1,3,13=3$ total & $18: 2,4-6,8-10,14-16=11$ total \\
\hline
\end{tabular}

I shall just briefly list other examples of pericopes where the angel of the LORD and Yahweh are juxtaposed:

Genesis 22:11-18: The binding of Isaac - the angel of the LORD calls to Abraham, commands him to release Isaac and render another sacrifice, and promises that his descendants will be 'as numerous as the stars of heaven'.

Exodus 3: The burning bush-the angel of the LORD calls to Moses from the burning bush, commands him to bring the people out of Egypt, and promises to protect the people from Pharaoh.

Judges 6:11-18: Gideon at Ophrah-the angel of the LORD appears to Gideon under a tree; Yahweh commands Gideon to conquer the Midianites; Yahweh promises to be with the Israelites and deliver their enemies up to them.

Judges 6:21-24: Gideon presents a sacrifice to Yahweh-Gideon gives sacrificial food to the angel of the LORD under the tree, Yahweh promises Gideon that he will not die as a result of seeing God, and

Doubleday, 1992), 248-53, 250.

7 G. von Rad, Genesis: A Commentary (London: SCM Press, 1972), 206. See also Justin Martyr, Dialogue 56 and 126. 
Yahweh commands Gideon to build an altar on the site of Yahweh's appearance.

Judges 13:3-22: Manoah's barren wife-the angel of the LORD appears to the wife of Manoah, promises her that she will bear a child, commands her not to eat or drink strong drink, the angel of the LORD appears again to Manoah to confirm what his wife has been told, Manoah says in 13:22 'We shall surely die, for we have seen God.'

\section{Structure of appearances}

There seems to be a clear pattern in each of the passages where we find the angel of the LORD and Yahweh appearing interchangeably. It is summarised in this table:

\begin{tabular}{|c|c|c|c|c|}
\hline & $\begin{array}{c}\text { Call or } \\
\text { appearance }\end{array}$ & Command & Promise & Foretelling \\
\hline $\begin{array}{c}\text { Genesis } \\
16: 7-13\end{array}$ & 7 & 9 & 10 & 12 \\
\hline $\begin{array}{c}\text { Genesis } \\
18: 1-16\end{array}$ & 1 & & $10 \& 14$ & \\
\hline $\begin{array}{c}\text { Genesis } \\
2: 11-18\end{array}$ & $11 \& 15$ & 12 & 17 & 18 \\
\hline Exodus 3 & 2 & 10 & 17 & \\
\hline $\begin{array}{c}\text { Judges } \\
6: 11-16\end{array}$ & 11 & 14 & 16 & 16 \\
\hline $\begin{array}{c}\text { Judges } \\
6: 21-24\end{array}$ & 21 & 20 & 23 & \\
\hline $\begin{array}{c}\text { Judges } \\
3: 3-22\end{array}$ & $3 \& 9$ & $4 \& 14$ & $3-5$ & 5 \\
\hline
\end{tabular}

All have the appearance of the angel of the LORD and Yahweh and a promise. All but one have a command and nearly $60 \%$ have a foretelling of some future event. The pattern of appearance, command, promise, and, in most cases, a foretelling of some event has the weight of divine intervention in human lives. Eichrodt relates the 'angel of the LORD' to the divine Glory, Presence, and Name ${ }^{8}$ and all of the personalities in these passages respond with the appropriate and expectable levels of awe and reverence.

8 W. Eichrodt, Theology of the Old Testament (Philadelphia: Westminster, 1967). 


\section{The meaning of the juxtaposition of the angel of the LORD and Yahweh}

As widely noted as the device of interchangeability of the angel of the LORD and Yahweh is, it is surprising to find so little in the literature that satisfactorily explains this phenomenon. In this connection Olyan notes 'Any comprehensive presentation of the angelic beliefs of ancient Jewish circles would be premature at this juncture, even though scholars have noted the lack of such study for many decades.' 9

Nonetheless, there are a number of notions about why we find the angel of the LORD and Yahweh appearing interchangeably in the same pericopes. For example, Noll observes that angels in hymns in the Qumran Hodayot text seem to serve a rhetorical function. He says '....angels are mentioned only in those sections where the lowliness of man is contrasted with the majesty of God. Rhetorically the angels serve as a foil for God, setting him off from every created thing. They also represent a point of comparison on the hierarchic scale of creation between man and God.' 10 Bloom makes a similar point. Discussing Moses before the burning bush in which God is disguised as an angel, Bloom says: 'Recall that nowhere does Yahweh say to Abram, Jacob, and the beloved David that they are not to approach too near. Indeed, never before has Yahweh spoken of the category of the holy, evidently invented to keep Moses and the mass of Israelites at a distance.' 11 This new idea of holiness demands an intermediary; humans cannot speak with the transcendent God and God will not deign to speak directly with humans. Although he does not say so regarding angels per se, I suspect that Bloom sees this device emerging from J's high opinion of David and his kingship. Thus, Yahweh is shown in a 'kingly', that is to say, distant position vis-à-vis God's people.

In the first truly comprehensive treatment of angelology in the OT done fifty years ago, Heidt ${ }^{12}$ offers three explanations for the interchangeability of the angel of the LORD and Yahweh. The first explanation Heidt calls the Logos Theory. It holds that the manifested angel is not Yahweh, but the second person of the Trinity, Jesus Christ. Heidt dismisses this theory on two grounds: (a) there is no

9 S.M. Olyan, A Thousand Thousands Served Him: Exegesis and the Naming of Angels in Ancient Judaism (Tübingen: J.C.B. Mohr [Paul Siebeck], 1993), 36.

10 S.F. Noll, Angelology in the Qumran Texts, 85.

11 D. Rosenberg and H. Bloom, The Book of $J$ (New York: Grove Weidenfeld, 1990), 244.

12 W.G. Heidt, Angelology of the Old Testament: A Study in Biblical Theology. 
evidence in the texts of the OT that there was any awareness of a plurality of the persons of God; and (b) there is positive emphasis throughout the OT on the unicity of God.

Heidt's second explanation, the Representation Theory, was widely held during the middle of this century by Roman Catholic writers. This theory holds that the angel is a divine messenger sent by God to humanity as an ambassador. Heidt, himself a Roman Catholic, challenges this theory by showing that there is no acknowledgement by the angels in the texts that they are, in fact, acting as ambassadors. This theory seems to follow the Vulgate's usage of nuntius versus angelus referred to earlier. Heidt points out that if an angel were truly an ambassador one would expect an opening phrase such as 'thus says Yahweh' or the angel would show credentials as a bona fide ambassador. My own objection to this theory is, as I have already pointed out, that the use of the angel as a 'stand-in' for God is inconsistent even within specific stories. Thus, a generous evaluation of this theory might allow it to be, notwithstanding Heidt's objections, an explanation for the presence of the angel, but not of the interchangeability problem we are discussing.

The Interpolation Theory, Heidt's third offering, suggests that the theological ideas of the people of Israel were transformed over the course of its long history and the 'angel of the LORD' was added to the text in those instances where the operations of Yahweh seemed too anthropomorphic. Heidt's opinion is that this theory falls apart

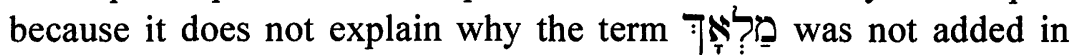
many other passages where Yahweh appears and speaks.

Heidt concludes with this synthesis:

'The theology of the angels was stressed or disregarded according to the demands of the more important Jewish beliefs; preceding the exile angels played an exceedingly minor role in Israelitic religious history because the prophets found it necessary to emphasize monotheistic Yahwism; during and after the exile monotheism was triumphant, Yahweh became increasingly transcendent and accordingly it became useful, even necessary to project a world of angels between God and man. Contact with Babylonian and Persian spirit-mythology during the exile aided in swelling the content and in diffusing angelological notions among the Jews. ${ }^{13}$

One of the best explanations put forth for the interchangeability problem is from Newsom. She suggests the narrators wish to employ

13 W.G. Heidt, Angelology of the Old Testament: A Study in Biblical Theology, 101-102. 
tension and paradox. 'Yahweh's authority and presence in these encounters is to be affirmed, but yet it is not possible for human beings to have an unmediated encounter with God.' In Genesis 16:7ff., for example, Hagar is correct; she has seen God. But it is also

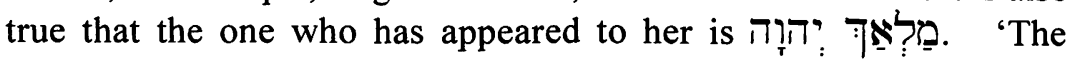
unresolved ambiguity in the narrative allows the reader to experience the paradox.' 14

In conclusion, while I agree with Newsom that the interchangeability of the angel of the LORD and Yahweh is a literary device to create tension, I also believe it may reflect different usage of source and editor whose purpose was to place distance between Yahweh and humanity in order to emphasise the transcendence of Yahweh. In this sense, then, 'angel of the LORD' is a euphemism for God. It is God who speaks to Hagar, Abraham, Manoah and his wife, and Gideon and it is God's appearances, commands, promises, and foretellings that we read in these passages. The variation between the use of device of the 'angel of the LORD' and the name of Yahweh serves both to emphasise God's transcendence when it is applied and to remind us who is really acting when it is not. Thus, I find myself in agreement with a position that blends Newsom's position and Heidt's synthesis cited above.

It was the variation between the use of the angel of the LORD and Yahweh in the passages cited that prompted me to write this paper. And it is this usage that causes me to think of the angel of the LORD as a euphemism for Yahweh. But when we think of a literary work with complex and varied sources like the OT, inconsistencies should not really trouble us too much. Also, it is unreasonable for us to expect of the authors of the OT a uniformity of thinking and belief about the character of God as God relates to humanity. As Newsom says 'Religious beliefs and forms of expression were probably no more uniform in ancient Israel than in any other age.' 15

14 C.A. Newsom, 'Angels', 250.

15 C.A. Newsom, 'Angels'. 